\title{
Paraoxonase 1 gene polymorphism and enzymatic activity as a prognostic marker in cases of poisoning by cholinesterase inhibitor pesticides among Egyptians
}

\author{
Ragaa T Darwish, Haidy M Megahed, MennattAllah H Attia ${ }^{1}$, Dalia A El-Neily² \\ ${ }^{1}$ Department of Forensic Medicine and Clinical Toxicology. \\ ${ }^{2}$ Department of Clinical Pathology. \\ Faculty of Medicine, University of Alexandria, Alexandria, Egypt.
}

\begin{abstract}
Paraoxonase1 (PON1) is a high-density lipoprotein associated A-esterase capable of hydrolysing activated metabolites (oxons) of several pesticides as organophosphorous, including chlorpyrifos, diazinon as well as carbamates. Human PON1 displays polymorphisms in the coding region (Q192R and L55M) and in the promoter and the 3'-UTR regions. Animal studies showed that high levels of PON1 protect individuals against acute organophosphatespoisoning. The PON1 genotype and enzymatic activity together contribute to determining an individual's PON1 "status".

In this study, the role of PON1 gene polymorphismsand its enzymatic activity was assessed as a prognostic marker in cases of acute poisoning by cholinestersase inhibitor (ChEI) pesticides among a sample of Egyptian population. Two equal groups of 100 unrelated individuals participated in the study: an exposed group and non-exposed group as control. Serum paraoxonase1 enzyme activitymeasured as arylesterase activity spectrophotometrically using the substrate phenyl acetate. PON1 Q192R gene was genotyped using PCR-RFLP technique.

The PON1 Q192R genotype frequency distribution in control subjects was (QQ=64\%, QR=28\%, RR=8\%) and in patients was $(\mathrm{QQ}=54 \%, \mathrm{QR}=42 \%, \mathrm{RR}=4 \%)$ and this was statistically significant $(\mathrm{p}=0.029)$. The arylesterase activity was significantly higher in control than exposed group $(\mathrm{p}=0.037)$. Regarding the effect of Q192R genotype and arylesterase activity on the outcome, there was no significant difference between the good and poor prognosis groups.

Evaluation of PON1 status may be important for determining individual susceptibility to poisoning by ChEI pesticides. However, the estimated level of arylesterase after exposure to poisoning can't be used in prediction of prognosis. Moreover, the coding genes show discrepant results even within the same ethnic group.
\end{abstract}

Keywords Paraoxonase 1 arylesterase activity, PON1 Q192R genotype, cholinestersase inhibitor pesticides

\section{Introduction}

holinesterase inhibitor pesticides poisoning is a serious public health problem in Egypt because of

their high morbidity and mortality in young adults. The organophosphorus and carbamates are the most popular cholinesterase inhibitor pesticides used as pest control in both the agricultural sector and residential use(Mansour, 2011).

Acute exposure to carbamates and organophosphorus are clinically indistinguishable. Both of them inhibit cholinesterase enzyme activity leading to accumulation of acetylcholine which overstimulates nicotinic and muscarinic receptors. However, in carbamates the chemical bond is reversible leading to shorter duration of toxicity(Pope et al., 2005).

There are multiple factors that lead to high susceptibility to poisoning by cholinesterase inhibitors pesticides. One of these factors is the interaction between genetic makeup of individuals and environmental exposurethat has been investigated in multiple studies. The role of the PON1 gene polymorphisms was always suspected due to previous animal knockout studies. They showed that high levels of PON1 protect individuals 
against acute organophosphates (OPs) toxicity(Costa et al., 2013).

Paraoxonase1(PON1) is a high-density lipoprotein (HDL) associated A-esterase present in plasma. PON1 enzyme is involved in the detoxification pathway of cholinesterase inhibitor pesticides. It canhydrolyzeactive oxons of several organophosphorous, including chlorpyrifos and diazinon as well as phenylacetate and carbamates(Li et al., 2000).

PON1 can be evaluated by its different activities, for example its paraxonase activity (when paraoxon is used as substrate), arylesterase activity (phenyl acetate is used as substrate) or by its lactonase activity (5-thiobutil butyrolactone -TBBL). The hydrolysis of phenylacetate can be used as a measure of protein levels(Ceron et al., 2014).

Human Paraoxonase 1 (PON1) displays polymorphisms in the coding region, the promoter and the 3'-UTR regions. Two polymorphisms in the coding region of PON1 gene have been identified and widely studied: (Q192R) in which a glutamine (Q) to arginine (R) substitution at codon 192 and a leucine (L) to methionine (M) substitution at position 55 (L55M). Five polymorphisms in the PON1 regulatory region were identified; these polymorphisms are at $-107 /-108,-126$, 160/-162, -824/-832, and -907/-909. Human PON1 gene polymorphisms affect either the catalytic efficiency of hydrolysis (coding region) or the expression level of PON1 (promotor)(Brophyet al., 2001).

The PON1 genotype and enzymatic activity contribute together in determining an individual's PON1 "status". The role of the PON1 status including PON1 gene polymorphisms and its serum enzymatic activity was always suspected due to previous animal knockout studies. Nevertheless, there is a huge debate in the scientific community regarding their role in protection against poisoning by cholinesterase inhibitors pesticides at different levels of exposure(Costa et al., 2013).

In this study, the role of PON1 gene polymorphismsand its enzymatic activity was assessed as a prognostic marker in cases of acute poisoning by cholinestersase inhibitor (ChEI) pesticides among a sample of Egyptian population.

\section{Materials and methods}

Patients and control subjects.Two groups of unrelated individuals participated in the study: an exposed group (patients) and non-exposed group (control). They were matched for ethnicity, age, sex and socioeconomic status. The exposed group consisted of50 patients suffering from acute poisoning by cholinesterase inhibitor pesticides and who were admitted to Poison centre in the main university hospital setting in Alexandria, Egypt, between December 2015 and March 2016. They were randomly selected based on certain exclusion criteria (pregnancy, chronic diseases, myopathy, myocardial infarction, trauma, malignancy or overwhelming sepsis and patients with mixed type of poisoning). The non- exposed group consisted also of 50 apparently healthy individuals without precedent occupational exposure to pesticides or any other industrial chemical.

Ethical consideration.The Ethical Committee of Alexandria faculty of medicine approved the protocol and procedures of this case-control study. All patients and control subjects were recruited upon obtaining informed consent. A valid consent was taken from each patient for obtaining medical history, clinical examination and for the permission to take blood samples for biochemical analysis. The collected clinical data were recorded anonymously and evaluated.Confidentiality of records were kept for all the data.

Clinical data. All individuals completed a detailed questionnaire covering standard demographic data (age, sex, occupation and socioeconomic status). All patients were subjected to complete history taking with special stress on the mode of poisoning, the period between intoxication and admission, type of working activity and use of protective measures. Thorough clinical examination focusing on confirming the poisoning by presence of symptoms and signs of cholinergic toxidrome and documentation of inhibited serum cholinesterase activity. The delay time between poisoning and admission was consistent in all cases being less than $12 \mathrm{~h}$. Management of patientswas based on patient's clinical condition regardless identity of the compound. Resuscitation was performed as usual protocol such as oxygen support, intravenous fluids, and maintaining electrolyte balance. The therapeutic protocols include atropine, oxime and benzodiazepine in conjunction with decontamination to prevent further absorption. Patients were seen frequently after admission to record the emergence of complications.

Biochemical parameters:Blood samples were collected into red capped tube for collection of serum. The analyses were done immediately. The tubes were centrifuged at $1000 \mathrm{rpm}$ for $10 \mathrm{~min}$. The resulting serum was separated then used for determination ofserum butrylcholinesteraseand PON1/arylesterase activities.

Assay of serum butrylcholinesterase(BChE) activity.BChE activity was estimated using the commercial kit of cholinesterase quantitative kinetic assay butyrylthiocholine (BTC) and dithiobisnitrobenzoic acid (DTNB) method on serum and plasma, BEN biochemical enterprise, Italy(Szasz, 1986).

Assay of PON1/arylesterase activity. PON1 activity was determined as arylesterase activity by monitoring the phenol quantity formed from phenyl acetate (Persico et al., 2008).

Molecular parameters: DNA study. The EDTA (lavender-top) vacutainers (BD diagnostics-preanalytic systems, UK) were used to collect blood from the participants for DNA analysis.Genomic DNA was extracted using QIAmp blood mini kit QIAGEN from the buffy coat of 100 blood samples following standard protocol provided by the manufacture. Polymerase chain 
reaction-restriction fragment length polymorphism (PCRRFLP) analysis was used to determine PON1 Q192R genotype.The primers (Biosearch technologies, USA) that were used to amplify genomic DNA fragments containing the polymorphic sites of Q192R in coding region (exon 6) of PON1gene sequences were described by Grdić et al. in(2008).

\section{Results}

Demographic data of patients and control subjects.The mean age of the patients $(n=50)$ was $33.24 \pm 13.51$ (range: $13-80$ ) years. The control subjects' mean of age was $34.76 \pm 16.15$ (range: 16.0 - 85.0) years. In both patients and control subjects, females outnumbered males with a sex ratio of 1.38:1 and 1.94:1 respectively. There was no significant difference between patients and control subjects regarding the age and sex.Table (2)

Statistical analysis. Data were analysed using SPSS software package for Windows version 20.0 (SPSS, Chicago, IL, USA). All data were collected either as dichotomous variables (eg, gender, outcome and genotype) or as discrete. Baseline variables and circumstances of poisoning were summarized with frequencies (percentages) for categorical variables and mean (standard deviation (SD)) for continuous variables (PON1/arylesterase activity).

\section{Clinical data}

The route of exposure was predominately ingestion (80\%). Other methods of exposure were inhalation in 7 patients (14\%), and combined dermal exposure and inhalation in 3 patients (6\%). Pie chart (1)

Regarding the circumstances of exposure, attempted suicide (52\%) was the most common cause of intoxication. Previous psychiatric disorders were reported in $4 \%$ of the cases. Family conflicts and economic hardships were the major precipitating factors for suicide (96\%). The accidental exposure (36\%) was due to bystander exposure, application of anti-lice treatment or consumption of food items containing pesticide residues. The occupational exposure (12\%) was due to faulty preparation and application of pesticides, lack of protective equipment and ignorance of the danger of pesticides. Pie chart (2)

Out of the 50 patients admitted to the Alexandria Poison centre (APC), 8 patients were transferred to the intensive care unit (ICU). They were presented with full-blown picture of acute cholinergic toxidrome. The clinical outcome was described as good and poor prognosis. The good prognosis group of patients $(n=42,84 \%)$ consisted of those who recovered completely. The poor prognosis group of patients $(n=8,16 \%)$ are those who survived but have a complicated clinical course $(n=5,10 \%)$ like respiratory failure, central nervous system (CNS) complications i.e. brain oedema, intermediate syndrome andthose who died due any of the above mentioned complications and any other complications $(n=3,6 \%)$.Pie chart (3)
The complications of poisoning were divided into respiratory failure $(n=5,10 \%)$, brain oedema $(n=2$, $4 \%)$ and intermediate syndrome $(n=3,6 \%)$.Overlapping complications occurred in 2 patients where brain oedemacoincides with respiratory failure. The deaths in our study occurred within 72 hours of admission to hospital. The causes of death were irreversible respiratory depression $(\mathrm{n}=2)$ or cardiac arrest $(\mathrm{n}=1)$. Table (3)

\section{Biochemical parameters}

Assay of butrylcholinesterase activity.Table (4) indicates the mean serum butrylcholinesterase enzyme activity in patients was significantly lower than in controls (p $<0.001$ ). At admission, the mean BuChE activity in patients was $4417.8 \pm 3135.4 \mathrm{U} / \mathrm{L}$.

Assay of PON1/arylesterase activity. The mean serum arylesterase activity was significantly lower in patients $(65.77 \pm 45.89 \mathrm{U} / \mathrm{ml})$ than in control groups $(83.51 \pm$ $50.13 \mathrm{U} / \mathrm{ml})(\mathrm{p}=0.037)$. The mean serum arylesterase activity showed also a wide inter-individual variation ranging from 16.40 to $209.0 \mathrm{U} / \mathrm{ml}$ and from 19.0 to 228.0 $\mathrm{U} / \mathrm{ml}$ in patients and control, respectively. Table (4)

Association between Paraoxonase1/Aryl esterase activity and prognosis of poisoning.The mean levels of arylesterase activity was higher in good prognosis group $69.68 \pm 48.71 \mathrm{U} / \mathrm{ml}$ than poor prognosis group $45.29 \pm 23.98 \mathrm{U} / \mathrm{ml}$. However, it wasn't significant $(\mathrm{p}=0.204)$. Table (5)

\section{Molecular parameters}

DNA studyof Q192R polymorphism.Undigested fragment (238 bp) was detected in homozygotes for Q192 allele (genotype QQ) in lanes: 2, 5, 6, 8, 9 ,13 and 16. Digested fragments (175 and $63 \mathrm{bp}$ ) were detected in homozygotes for R192 allele (genotype RR) lane: 15. Both digested and undigested fragments (238, 175 and 63 bp) were detected in heterozygotes (genotype QR) in lanes: 1,3, 4,7, 10,11,12 and 14 . The relation between the resultant bands, PCR fragment size and relation to genotyping are demonstrated in Table (1) and Figure (4). The distribution offrequenciesfor PON1Q192R gene polymorphisms.The genotype frequency of PON1 Q192R was conformed to the Hardy-Weinberg equilibrium in both patients and controls. Table 13 showed that in control subjects, the homozygous (QQ) was the most common genotype followed by heterozygous (QR)followed by homozygous mutated gene (RR) and their frequency were 32 (64\%), 14 (28\%) and $4(8 \%)$, respectively. In patients, the heterozygous (QR) was the most common genotype [27 (54\%)] followed by (QQ) [21 (42\%)] then the homozygous mutated gene (RR) [2 (4\%)]. The frequency of the Q allele was found to be $69(69 \%)$ and 78 (78\%), while that of the mutated R allele was 31(31\%) and 22 (22\%) in the patients and control group, respectively. There was a significant difference in the distribution of PON1 Q192R genotypes between patients and control groups ( $\mathrm{p}$ $=0.029$ ). However, the frequency distribution of the $\mathrm{Q}$ 
and $\mathrm{R}$ alleles wasn't significantly different between patients and control groups ( $\mathrm{p}=0.149$ ). Table (6)

Effect of PON1Q192R genotype on the level of PON1/arylesterase activity. As regard serum PON1 arylesterase activity, PON1Q192R genotype have no significant effect on activity in both patients and control. The mean arylesterase activity in homozygous QQ genotype was higher thanheterozygous QR genotype in both patients and control. However, the mean arylesterase activity in RR genotype was variable, representing lowestvalue in patients and highest value in controlgroups. Table (7)

Association of coding Q192R PON1 gene polymorphismwith prognosis. Q192R genotype, Qand R alleles frequency distribution was not significantly different between the good and poor prognosis groups $(\mathrm{p}=1.000$ and $=0.571$, respectively). Table(8)

Table (1): Q192R gene primer sequences used in amplification by PCR and RFLP conditions

\begin{tabular}{|c|c|c|c|c|}
\hline Polymorphism & Primer sequence & $\begin{array}{l}\text { Restriction } \\
\text { enzyme }\end{array}$ & $\begin{array}{l}\text { PCR } \\
\text { fragment }\end{array}$ & $\begin{array}{l}\text { RFLP } \\
\text { fragments }\end{array}$ \\
\hline Q192R & $\begin{array}{l}\text { PON1-192-F-25: (forward) } \\
\text { 5'TATTGTTGCTGTGGGACCTGAG 3' } \\
\text { PON1-192-R-25: (reverse) } \\
\text { 5'CCTGAGAATCTGAGTAAATCCACT } \\
\text { 3' }\end{array}$ & BspPI & 238 bp & $\begin{array}{l}\text { Q allele: } \\
238 \text { bp } \\
\text { R allele: } \\
175 \text { and } 63 \text { bp }\end{array}$ \\
\hline
\end{tabular}

Table (2):Chi square and Mann Whitney tests for comparison between the 50 patients and 50 control groups according to demographic data.

\begin{tabular}{|c|c|c|c|c|c|c|}
\hline & \multicolumn{2}{|c|}{$\begin{array}{c}\text { Patients } \\
(n=50)\end{array}$} & \multicolumn{2}{|c|}{$\begin{array}{l}\text { Control } \\
(n=50)\end{array}$} & \multirow[t]{2}{*}{ Test of sig. } & \multirow[t]{2}{*}{$\mathbf{p}$} \\
\hline Sex & No & $\%$ & No & $\%$ & & \\
\hline Male & 21 & 42.0 & 17 & 34.0 & \multirow{2}{*}{$\chi^{2}=0.679$} & \multirow{2}{*}{0.409} \\
\hline Female & 29 & 58.0 & 33 & 66.0 & & \\
\hline \multicolumn{7}{|l|}{ Age } \\
\hline Min. - Max. & \multicolumn{2}{|c|}{$13.0-80.0$} & \multicolumn{2}{|c|}{$16.0-85.0$} & \multirow{3}{*}{$Z=0.152$} & \multirow{3}{*}{0.881} \\
\hline Mean \pm SD. & \multicolumn{2}{|c|}{$33.24 \pm 13.51$} & \multicolumn{2}{|c|}{$34.76 \pm 16.15$} & & \\
\hline Median & \multicolumn{2}{|c|}{30.0} & \multicolumn{2}{|c|}{30.0} & & \\
\hline
\end{tabular}

2: Chi square test, $Z, p: Z$ and $p$ values for Mann Whitney test

Table (3):Distribution of 50 patients according to the complications of poisoning and causes of death

\begin{tabular}{|l|c|c|}
\hline Complications of poisoning and causes of death & No & $\mathbf{\%}$ \\
\hline Respiratory failure & 5 & 10.0 \\
\hline Brain oedema & 2 & 4.0 \\
\hline Intermediate syndrome & 3 & 6.0 \\
\hline Cardiac arrest & 1 & 2.0 \\
\hline Irreversible respiratory depression & 2 & 4.0 \\
\hline
\end{tabular}

Table (4):Mann Whitney test, the butrylcholinesterase andPON1/arylesterase activity in patients with acute poisoning by ChEIpesticides and control groups.

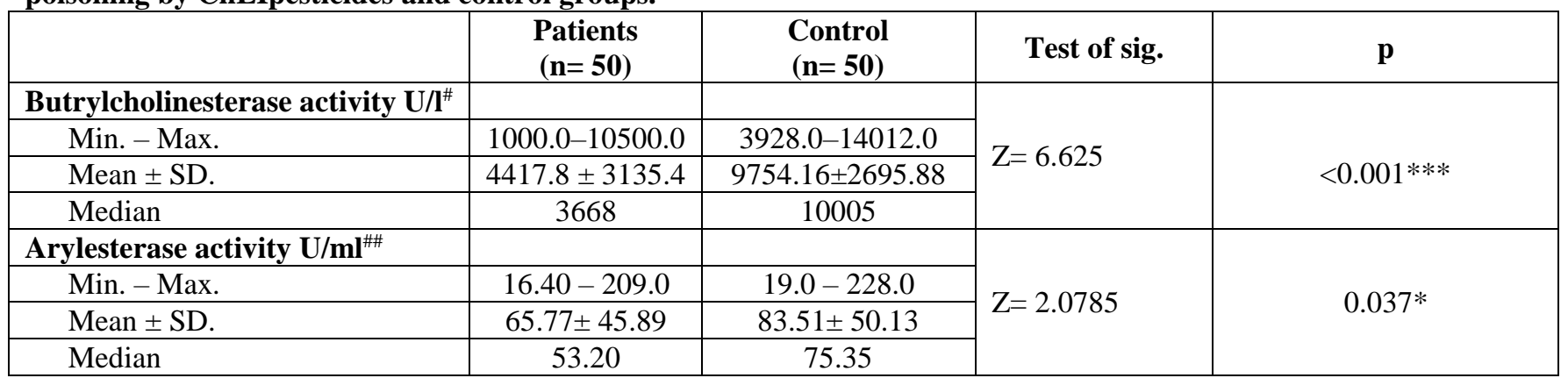

Z, p: Z and $p$ values for Mann Whitney test, ***: highly significant, *: Statistically significant at $p \leq 0.05$, \#Reference value for BChE activity: 4900 -11900 U/l ,\#\#High arylesterase activity >145 U/ml, moderate activity (124-145 U/ml) and low activity $<124 \mathrm{U} / \mathrm{ml}$ 
Table (5):Mann Whitney testanalysis for the relation between PON1/arylesterase activity and prognosis of poisoning.

\begin{tabular}{|c|c|c|c|c|}
\hline & $\begin{array}{c}\text { Good prognosis } \\
(\mathbf{n = 4 2})\end{array}$ & Poor prognosis (n=8) & $\mathbf{Z}$ & $\mathbf{p}$ \\
\hline Aryl esterase activity U/ml & & & & \\
\hline Min. - Max. & $16.4-209$ & $21.2-83$ & \multirow{2}{*}{0.27021} & 0.204 \\
\hline Mean \pm SD. & $69.68 \pm 48.71$ & $45.29 \pm 23.98$ & & \\
\hline Median & 54.8 & 34.85 & & \\
\hline
\end{tabular}

$Z, p: Z$ and $p$ values for Mann Whitney test \#High arylesterase activity $>145 \mathrm{U} / \mathrm{ml}$, moderate activity (124-145 U/ml) and low activity $<124 \mathrm{U} / \mathrm{ml}$

Table (6): Chi square test, the distribution of the PON1 Q192R polymorphism, $Q$ and $R$ alleles frequencies in patients $(n=50)$ and control $(n=50)$ groups.

\begin{tabular}{|c|c|c|c|c|c|c|c|}
\hline \multirow{2}{*}{\multicolumn{2}{|c|}{-1}} & \multicolumn{2}{|c|}{$\begin{array}{c}\text { Patients } \\
(n=50)\end{array}$} & \multicolumn{2}{|c|}{$\begin{array}{l}\text { Control } \\
(n=50)\end{array}$} & \multirow[t]{2}{*}{$\chi^{2}$} & \multirow[t]{2}{*}{$\mathbf{p}$} \\
\hline & & $\mathbf{N}$ & $\%$ & $\mathbf{N}$ & $\%$ & & \\
\hline \multirow{3}{*}{ Q192R } & $\mathrm{QQ}$ & 21 & $42.0 \%$ & 32 & $64.0 \%$ & \multirow{3}{*}{7.0716} & \multirow{3}{*}{$0.029 *$} \\
\hline & $\mathrm{QR}$ & 27 & $54.0 \%$ & 14 & $28.0 \%$ & & \\
\hline & RR & 2 & $4.0 \%$ & 4 & $8.0 \%$ & & \\
\hline \multirow{2}{*}{ Allele } & $\mathrm{Q}$ & 69 & 69.0 & 78 & 78.0 & \multirow{2}{*}{2.0793} & \multirow{2}{*}{0.149} \\
\hline & $\mathrm{R}$ & 31 & 31.0 & 22 & 22.0 & & \\
\hline
\end{tabular}

$\chi 2$ : Chi square test $*$ : Statistically significant at $p \leq 0.05$

Table (7): Kruskal Wallis test analysis for the relation between PON1Q192R genotypes with PON1/arylesterase activityin patientsand control groups

\begin{tabular}{|c|c|c|c|c|c|}
\hline \multirow[b]{2}{*}{ Aryl esterase Activity U/ml ${ }^{\#}$} & \multicolumn{3}{|c|}{ PON1Q192R genotypes } & \multirow{3}{*}{$\mathrm{K}^{\mathrm{w}}$} & \multirow{3}{*}{$\mathbf{p}$} \\
\hline & QQ & QR & $\mathbf{R R}$ & & \\
\hline Patients & $n=21$ & $\mathbf{n}=\mathbf{2 7}$ & $n=2$ & & \\
\hline Min. - Max. & $16.4-181.2$ & $18.1-209$ & $49-60.68$ & \multirow{3}{*}{0.282} & \multirow{3}{*}{0.596} \\
\hline Mean \pm SD. & $68.14 \pm 43.41$ & $64.74 \pm 49.169$ & $54.84 \pm 5.84$ & & \\
\hline Median & 53.4 & 52.4 & 54.84 & & \\
\hline Control & $n=32$ & $n=14$ & $n=4$ & \multirow{4}{*}{0.655} & \multirow{4}{*}{0.721} \\
\hline Min. - Max. & $20.1-228$ & $24.8-190$ & $19-195.3$ & & \\
\hline Mean \pm SD. & $83.059 \pm 42.485$ & $82.811 \pm 58.19$ & $89.55 \pm 71.267$ & & \\
\hline Median & 77.7 & 62.48 & 71.95 & & \\
\hline
\end{tabular}

Table (8): Chi square test analysis for the relation between the Q192R genotype, $Q$ and $R$ alleles and prognosis of poisoning in patients group

\begin{tabular}{|c|c|c|c|c|c|c|}
\hline & \multicolumn{4}{|c|}{ Good prognosis Bad prognosis } & \multirow{3}{*}{$\chi^{2}$} & \multirow{3}{*}{$\mathbf{p}$} \\
\hline & \multicolumn{2}{|c|}{$(n=42)$} & \multicolumn{2}{|c|}{$(n=8)$} & & \\
\hline & No & $\%$ & No & $\%$ & & \\
\hline QQ & 17 & $40.5 \%$ & 4 & $50.0 \%$ & & \\
\hline QR & 23 & $54.8 \%$ & 4 & $50.0 \%$ & 0.554 & 1.000 \\
\hline $\mathbf{R R}$ & 2 & $4.8 \%$ & 0 & $0.0 \%$ & & \\
\hline Q allele & 57 & $67.9 \%$ & 12 & $75 \%$ & & \\
\hline $\mathbf{R}$ allele & 27 & $32.1 \%$ & 4 & $25 \%$ & 0.32 & $0.0 / 1$ \\
\hline
\end{tabular}

ఒ: Chi square test 


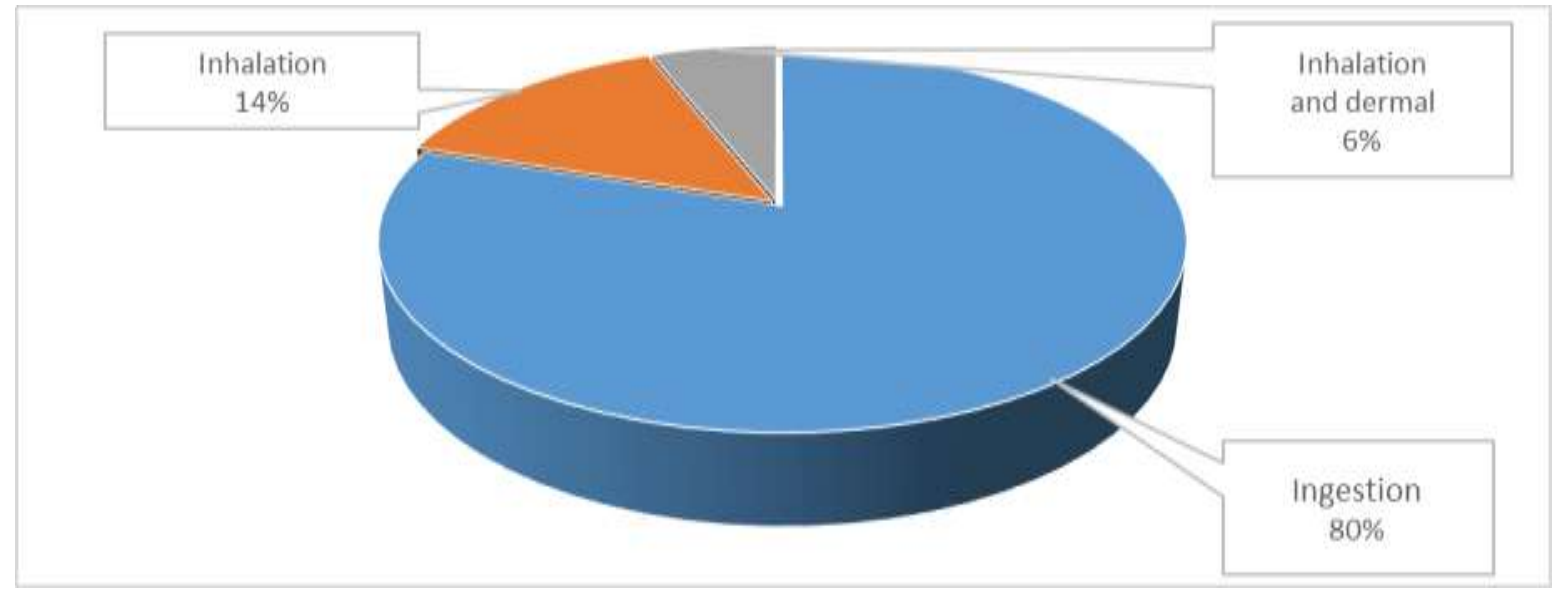

Pie chart (1):Distribution of patients according to route of exposure $(n=50)$

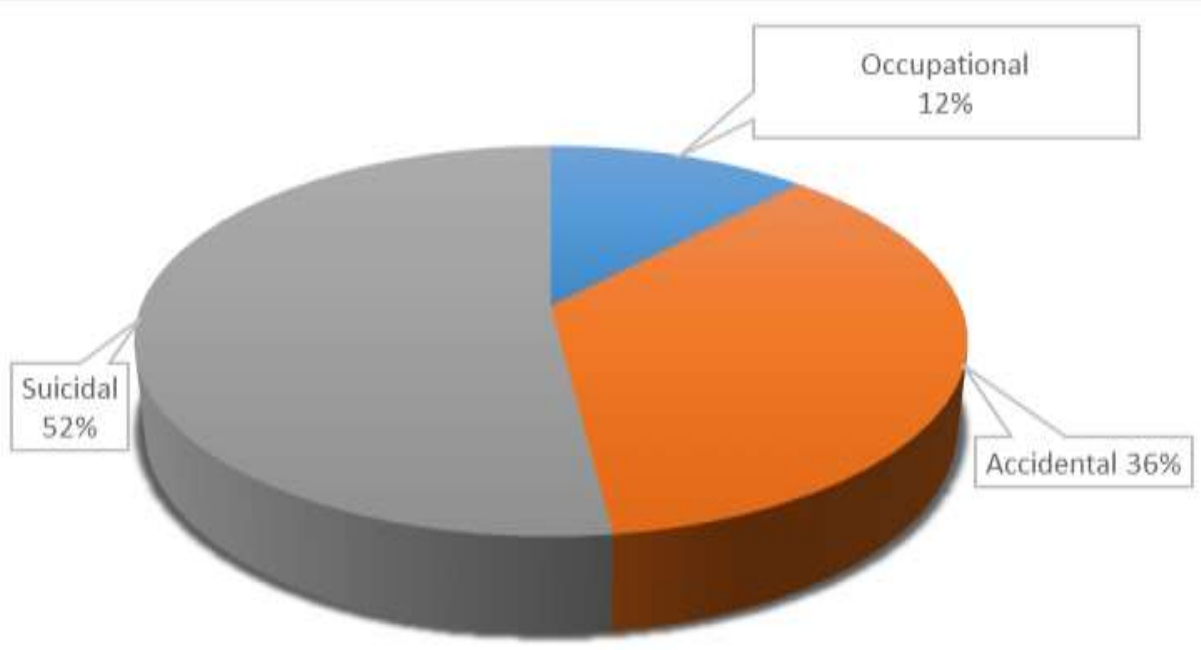

Pie chart(2): Distribution of patients according to circumstances of exposure $(n=50)$

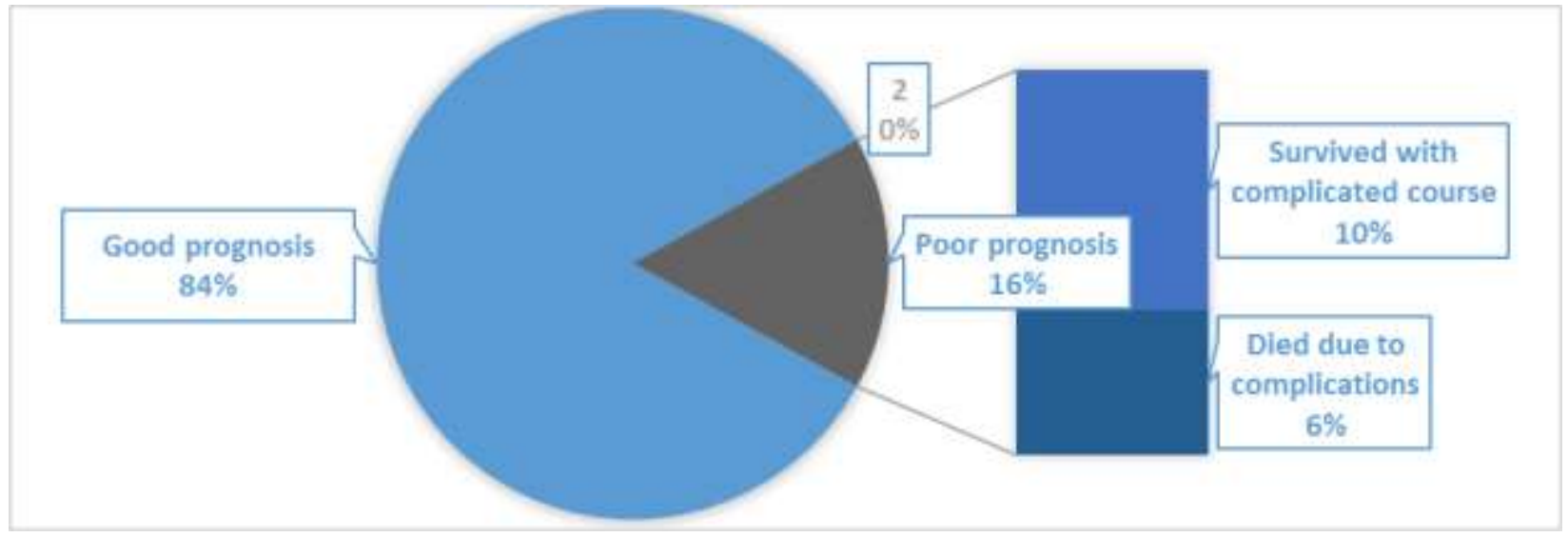

Pie chart (3): Distribution of patients according to prognosis of poisoning (n=50) 


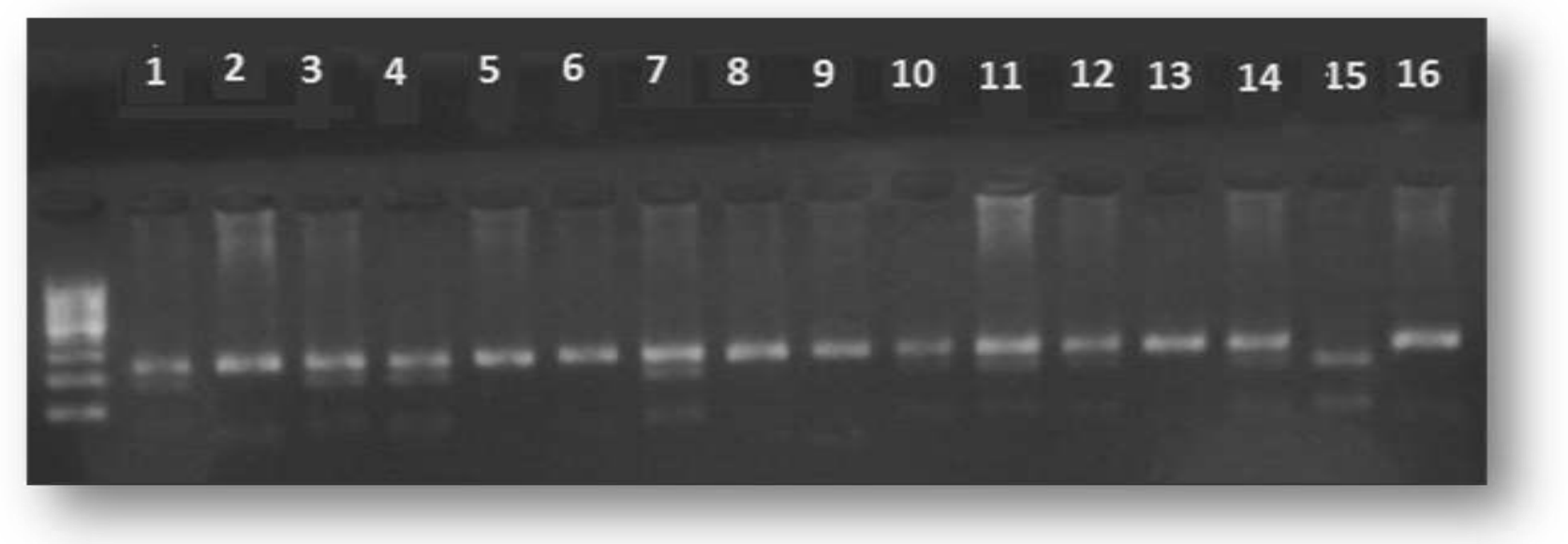

Figure (4): The gel electrophoresis showing relation between the resultant bands, PCR fragment size and Q192R polymorphism

\section{Discussion}

In this study, the role of PON1 gene polymorphismsand its enzymatic activity was assessed as a prognostic marker in cases of acute poisoning by cholinestersase inhibitor (ChEI) pesticides among a sample of Egyptian population. Two equal groups of 100 unrelated individuals participated in the study: an exposed group and non-exposed group as control subjects. Serum paraoxonase1 enzyme activity measured as arylesterase activity spectrophotometrically using the substrate phenyl acetate. PON1 Q192R gene was genotyped using PCR-RFLP technique.

The mean age is in the productive age group in both patients and control (33.24 \pm 13.51 and 34.76 \pm 16.15 years, respectively). The present study reveals the predominance of females in both patients and control subjects with overall male to female ratio 1:1.38 and 1:1.94, respectively. This age and sex pattern is consistent with mean age in developing countries and indicates a predominance of non-occupational type of poisoning because females in this age group are subjected to substantial amount of mental stress and strain.The results were in agreement with those by Yurumez et al. (2009) and Gazzi et al. (2015).

Acute OP exposure can be subcategorised into suicidal, accidental and occupational. This study demonstrates that intentional self-poisoning and oral route $(80 \%)$ were the most common type of exposure. This was in accordance with other results by Eddleston et al. (2006) and Kora et al. (2011).

The higher percentage of suicidal attempts could be attributed to the low-price, easy availability and, in addition to, the lack of adequate regulations controlling their sale. They usually involve ingestion of a large amount, which can lead to rapid onset of the clinical features and complicating the management.

In (2016) Parate et al. showed that moderate to severe cases of OP poisoning have higher morbidity and mortality. This explains that the severely ill patients were admitted to ICU.

In the present study, the mortality rate was low, 3 (6\%) out of 50 patients. A low mortality rate might be due to short time lapse between the exposure and hospital admission. This is in agreement with Churi et al (2012) who depicted mortality rate as $5.1 \%$ in their study.

The present work showed thatfew patients developed complications in the form of respiratory failure $(n=5,10 \%)$, brain oedema $(n=2,4 \%)$ and intermediate syndrome $(\mathrm{n}=3,6 \%)$. This is in agreement with Chintaleet al. (2016) whoconducted a study on 98 patients suffering from acute organophosphorus poisoning where respiratory failure complicated $8.08 \%$ of them, intermediate syndrome developed in 6 cases (4.41\%), 3 patients (2.20\%) had aspiration pneumonia, 2 patients $(1.47 \%)$ had circulatory collapse and 1 patient $(0.73 \%)$ had septic shock.

In the current study, BuChE inhibition was used as a quantitative biomarker of OP/CB exposure and the mean serum BuChE enzyme activity in patients was approximately $50 \%$ and significantly lower than in controls ( $\mathrm{p}<0.001$ ). The mean BuChE activity was $4417.8 \pm 3135.4 \mathrm{U} / \mathrm{L}$ and $9754.16 \pm 2695.88 \mathrm{U} / \mathrm{L}$ in patient at admission and control subjects respectively. This was in agreement with the study conducted by Sözmen et al. (2002).

Concerning the mean serum arylesterase activity, our results showed a wide inter-individual variation ranging from 16.40 to $209.0 \mathrm{U} / \mathrm{ml}$ and from 19.0 to $228.0 \mathrm{U} / \mathrm{ml}$ in patients and control, respectively. These results were consistent with those reported by Rojas-García et al. (2005).

Furthermore, the mean serum arylesterase

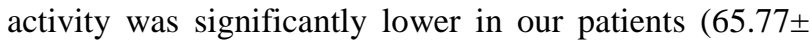
$45.89 \mathrm{U} / \mathrm{ml}$ ) when compared to control group (83.51 $50.13 \mathrm{U} / \mathrm{ml})(\mathrm{p}=0.037)$. This was consistent with results postulated by Sözmen et al. (2002) and Zhang et al. 
(2010) who found that PON1 activity was $114.2+/-67.4$ $\mathrm{nmol} / \mathrm{mL} / \mathrm{min}$ versus $152.9+/-78.9 \mathrm{nmol} / \mathrm{mL} / \mathrm{min}$ and $70.2 \pm 19.6 \mathrm{U} / \mathrm{ml}$ versus $125.1 \pm 20.9 \mathrm{U} / \mathrm{ml}$, in patients and control respectively $(\mathrm{p}<0.05)$.

This observation is true even in the context of occupational exposure. In (2011) Singh et al. showed thatPON1 activity toward phenylacetate was significantly lower in workers $112.74 \pm 17.37 \mu \mathrm{mol} / \mathrm{min} / \mathrm{ml}$ than in control $134.28 \pm 25.49 \mu \mathrm{mol} / \mathrm{min} / \mathrm{ml}$ in controls, $(\mathrm{p}<0.001)$.

Paraoxonase-1 (PON1) enzyme plays an important role as an endogenous free-radical scavenging molecule. The decrease in serum arylesterase activity in the exposed group might result from its inactivation via lipid peroxidation due to the increased generation of reactive oxygen species upon accumulation of pesticides residues in blood. In addition, reactive oxygen molecules such as superoxide anions are generated subsequent to oxygen therapy used to treat hypoxemia present in the exposed group. Oxidative stress results from overproduction of reactive oxygen species and failure of the antioxidant defence systems (Sözmen et al., 2002; Ranjbar et al., 2005; Mecdad et al., 2011).

Regarding PON1Q192R genotyping in the exposed group, the frequency of the heterozygous $(\mathrm{QR})$ was the most common genotype followed by (QQ) which was followed by the homozygous mutated gene (RR). Their frequency were 27 (54\%), 21 (42\%) and 2 (4\%), respectively.

In a study on the PON1 Q192R polymorphism,Hussein et al. (2011)reported that the genotype frequencies of homozygous (QQ), heterozygous (QR), and homozygous mutated (RR) were $51 \%, 41 \%$, and $8 \%$ in patients, respectively. Although all the study population were females, yet the genotype frequencies are comparable.

In another study conducted by Helaly et al. (2013), the distribution of the genotypes was $\mathrm{QR}>\mathrm{QQ}>\mathrm{RR}$ in patients and control, being 45\%, 41\%, $14 \%$ and 49\%, $44 \%, 7 \%$ respectively.

Moreover, Ellison et al (2012) observed higher frequency of the QR genotype in her study population. The frequencies of genotypes were QR (45.8\%), QQ (40.0\%) and RR (14.2\%).

In this study, the frequency of the Q allele was found to be 69 (69\%) and 78 (78\%), while that of the mutated $\mathrm{R}$ allele was 31(31\%) and 22 (22\%) in the patients and control group, respectively. This is in agreement with the frequency published by Hussein et al. (2011) as well as Elfasakhany et al. (2014).

Moreover, the frequency distribution of the $\mathrm{Q}$ and $\mathrm{R}$ alleles wasn't significantly different between patients and control groups $(\mathrm{p}=0.149)$ indicating absence of susceptibility genetic factors between exposed and non-exposed group.

PON1Q192R genotypes have no significant effect on activity in both patients and control. Many studiesshowed that arylesterase activity isn't influenced by any of PON1 polymorphisms which is in agreement with our results(López-Flores et al., 2009;Sirivarasai et al., 2007;Gupta et al., 2011).

In contrast, some studies reported the influence of Q192R on PON1 arylesterase activity. These conflicting results about the effect of PON1 polymorphism on arylesterase activity can be explained by the fact thatPON1 activity can vary up to 40 -fold within a given population and protein levels can vary up to 13-fold for a single PON1 192 genotype (Rojas-García et al. 2005;Bednarska-Makaruket al. 2013).

Moreover, Huen et al. (2011)reported that there are many factors that may affectAREase activity particularly such as genetic variants in other genes, environmental exposure or epigenetic modification that may influence PON1expression.

Nevertheless, the mean arylesterase activity in QQ genotype was always higher than the QR genotype in both patients and control. However, the mean arylesterase activity in RR genotype was variable, being low in patients and high in the control.

In a study by Browne et al.(2011), individuals with RR had 1.46 fold higher arylesterase activity than QQ phenotype. This goes in hand with the mean arylesterase activity in control subjects. There were only two individuals that have the RR genotype, so the level of arylesterase can't be relied upon.

Regarding the effect of PON status on the outcome, the Q192R genotype frequency distribution was not significantly different $(\mathrm{P}=0.606)$ between the groups of good and poor prognosis. In agreement with our results, Ellison et al (2012) in a study done in Menoufia, found that PON1 Q192R genotype don't affect chlorpyrifos (CPF) related toxicity at low exposure conditions in workers occupationally exposed to CPF.

There arecontradictory reportsall over the world regarding which PON1Q192R genotype is more sensitive to OP exposure. This confusion ispresent even within the same ethnic group (Egyptian population). Zayed et al. (2015) and Khattab et al. (2016) observed that PON1 192 $\mathrm{RR}$ genotype and $\mathrm{R}$ allele were significantly increased in acute and chronic OP intoxicated patients respectively.

However,Morcos et al. (2015) suggested a possible relation between QR genotype and poor OP poisoning prognosis whilebetter prognosis was more related to RR genotype. This is because the

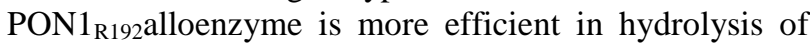
many commonly used OPs compared to the PON1 Q192 alloenzyme.

The controversy might arise from ethnic differences in PON1 single nucleotide polymorphism (SNP) genotyping and expression regulation. The difference in genotype distribution of PON-1 among Egyptians and other races may be due to the fact that Egyptian nation isn't homogenous. Egyptians are considered as a mixed race population, so the percentage 
of our participants can't be referred exclusively to the African or Caucasian population (Ellison et al.,2012;Khattab et al.,2016; Hofmann et al., 2009)

Finally, the seriously ill individuals (poor prognosis group) were exposed to very high doses of pesticides, as all died within $72 \mathrm{~h}$, and this would overcome any potential protection afforded by the PON1 $1_{\mathrm{Q} 192}$ genotype as it was concluded by Yamada et al. (2001) in the context of sarine terroristic attack in Japan.

The protection offered by the PON1-192Q and $\mathrm{R}$ alleles is variable in relation to the substrate (type of organophosphate in question) and degree of exposure (high or low exposure). It was confirmed that PON1 is not efficient at hydrolysing paraoxon at low concentrations in vivo, and that other pathways (e.g. CYP, carboxylesterase) might be responsible for detoxifying paraoxon (Pond et al.,1995)

Studies ofPON1genotypes and phenotypes in different ethnic populations have revealed significant variation in both allele frequencies and PON1 activities. For example, the frequency of the $\mathrm{PON}_{192 \mathrm{Q}}$ allele, which is associated with slower catalytic efficiency towards oxons of some OPs (e.g. chlorpyrifos), has a high frequency in Caucasians (73\%), but a significantly lower frequency in Mexicans (48\%) and African-Americans (37\%). The frequency of the protective PON1-192R allele increases to (70-90\%) in Far Eastern Oriental and Sub-Saharan African populations (Rojas-García et al., 2005; La Du et al.,1993).

Similarly, the frequency of the Q allele in our sample was high in both patients and control (69\% and $78 \%$, respectively) and the frequency of $\mathrm{Q}$ allele was slightly higher in good prognosis (67.9\%) than poor prognosis (75\%) in addition to absence of RR genotype in poor prognosis group. This can explain the increased sensitivity to poisoning in this group, despite of being non-significant.

Moreover, thenon-significant lower mean arylesterase activity estimated in the group of poor prognosis when compared to that of good prognosis indicates a higher redox state in the body because these individuals were exposed to very high doses of these toxic compounds(Veiga et al., 2011).

\section{Conclusion}

Evaluation of PON1 status may be important for determining individual susceptibility to increased risk of exposure to OP pesticides. However, PON1 Q192R genotype frequency distribution and arylesterase activity weren't significantly different between the good and poor prognosis groups. The significant decrease of PON/ arylesterase activity in patients is related to the acute exposure to ChEIpesticides and not to allelic or genotypic differences.

The current study suggest that subjects with higher paraoxonase1 activity may have a better chance of detoxifying the acute cholinesterase inhibitors pesticides poisoning. The estimated level after exposure to poisoning can't be used in prediction of prognosis. Moreover, the coding genes show discrepant results even within the same ethnic group (Egyptian population).

\section{Recommendations}

From the current study, it is recommended to increase the number of participants to be representative of patients in the general population. Furthermore, this study had focused on one locus on a single gene. Therefore, other genes associated with metabolism of ChEI pesticides should be studied to evaluate the effects of gene- gene interactions. Finally, given that outcomes probably reflect resource availability, outcomes in one poison centre are not necessarily the same as outcomes in another centre. The great variability in severity of toxicity and treatment response among organophosphorus and carbamates agents in various poison centres should be considered independently in future studies.

\section{References}

Bednarska-Makaruk ME, Krzywkowski T, Graban A et al., (2013):Paraoxonase 1 (PON1) gene-108C> T and p. Q192R polymorphisms and arylesterase activity of the enzyme in patients with dementia. Folia. Neuropathol. 51:111-9.

Brophy VH, Jampsa RL, Clendenning JB et al., (2001): Effects of 5' regulatory-region polymorphisms on paraoxonase-gene (PON1) expression. Am. J. Hum. Genet. 68(6):1428-36.

Browne RW, Koury ST, Marion S et al., (2011): Accuracy and biological variation of human serum paraoxonase 1 activity and polymorphism (Q192R) by kinetic enzyme assay. Clin. Chem. 53: 310-7.

Ceron JJ, Tecles F and Tvarijonaviciute A (2014): Serum paraoxonase 1 (PON1) measurement: an update. BMC veterinary research.10(1):1.

Chintale KN, Patne SV and Chavan SS (2016): Clinical profile of organophosphorus poisoning patients at rural tertiary health care center. Int. J. Adv. Med. 3(2):268-74.

Costa LG, Giordano G, Cole TB et al., (2013):Paraoxonase 1 (PON1) as a genetic determinant of susceptibility to organophosphate toxicity. Toxicology. 307:115-22.

Eddleston M, Sudarshan K, Senthilkumaran M et al., (2006): Patterns of hospital transfer for selfpoisoned patients in rural Sri Lanka: implications for estimating the incidence of selfpoisoning in the developing world. Bull. World. Health. Organ. 84: 276-82

Elfasakhany FM, Abou-Elnoeman SA, Hussein ME et al., (2014):Paraoxonase Activity and Gene Polymorphism in Rheumatoid Arthritis among Egyptians. Clinical Medicine and Diagnostics. 4(1A):15-20. 
Ellison CA, Crane AL, Bonner MR et al., (2012): PON1 Status Does Not Influence Cholinesterase Activity in Egyptian Agricultural Workers Exposed to Chlorpyrifos. Toxicol. Appl. Pharmacol. 265(3): 308-15.

Gazzi EN, Sorodoc V, Jaba IM et al., (2015): Profile of adult acute cholinesterase inhibitors substances poisoning-a 30 years analysis. Open Med.10(1): 278-84.

Grdić M, Barišić K, Rumora L et al., (2008): Genetic frequencies of paraoxonase 1 gene polymorphisms in Croatian population. Croatica. Chemica. Acta.81(1):105-11.

Gupta N, Binukumar BK, Singh S et al., (2011): Serum paraoxonase-1 (PON1) activities (PONase/AREase) and polymorphisms in patients with type 2 diabetes mellitus in a NorthWest Indian population. Gene. 487(1):88-95.

Hofmann JN, Keifer MC, Furlong CE et al., (2009): Serum cholinesterase inhibition in relation to paraoxonase-1 (PON1) status among organophosphate-exposed agricultural pesticide handlers. Environ. Health. Perspect. 117, 14028.

Huen K, Barcellos L, Beckman K et al., (2011): Effects of PON polymorphisms and haplotypes on molecular phenotype in Mexican-American mothers and children. Environ. Mol. Mutagen. 52(2):105-16.

Hussein YM, Gharib AF, Etewa RL et al., (2011): Association of L55M and Q192R polymorphisms in paraoxonase 1 (PON1) gene with breast cancer risk and their clinical significance. Mol. Cell. Biochem. 351(1-2):11723.

Khattab AM, Zayed AA, Ahmed AI et al., (2016): The role of PON1 and CYP2D6 genes in susceptibility to organophosphorus chronic intoxication in Egyptian patients. Neurotoxicology. 53:102-107.

Kora SA, Doddamani GB, Halagali GR et al., (2011): Sociodemographic Profile of the Organophosphorus Poisoning Cases in Southern India. Journal of Clinical and Diagnostic Research. 5(5): 953-6

La Du BN, Adkins S, Kuo CL et al., (1993): Studies on human serum paraoxonase/arylesterase. Chem. Biol. Interact. 87)1:(25-34.

Li WF, Costa LG, Richter RJ et al., (2000): Catalytic efficiency determines the in vivo efficacy of PON1 for detoxifying organophosphates. Pharmacogenetics.10:76779.

López-Flores I, Lacasaña M, Blanco-Muñoz J et al., (2009): Relationship between human paraoxonase-1 activity and PON1 polymorphisms in Mexican workers exposed to organophosphate pesticides. Toxicol. lett.188(2):84-90.

Mansour SA (2011): Epidemiological studies of Anticholinesterase pesticide poisoning in Egypt. In: Anticholinesterase pesticides: metabolism, neurotoxicity, and epidemiology, Satoh $\mathrm{T}$ and Gupta RC (eds), John Wiley \& Sons, USA. Ch27. pp.379-400.

Mecdad AA, Ahmed MH, ElHalwagy ME et al., (2011): A study on oxidative stress biomarkers and immunomodulatory effects of pesticides in pesticide-sprayers. Egyptian Journal of Forensic Sciences. 1(2):93-98.

Morcos NY, El-Masry MK, Kamal MM et al., (2015): Contrasting genetic influence of PON 1 coding gene polymorphisms L55M and Q192R on individuals' response to environmental agents. Egypt. J. Med. Hum. Genet.16(3):233-7.

Parate T, Parate R, Bhalerao N et al., (2016): Clinical Profile of Patients with Organophosphorus Poisoning in an Intensive Care Unit in a Tertiary Care Hospital. Global Journal for Research Analysis. 5(4):438-40.

Persico A, Sacco R and Lintas C (inventors), (2008): Measurement of arylesterase enzymatic activity and assessment of genetic polymorphisms located in the PON1 gene as a diagnostic tool in autism-spectrum disorders. United States patent application US 12/681,179.

Pond AL, Chambers HW and Chambers JE (1995): Organophosphate detoxication potential of various rat tissues via A-esterases and aliesterase activities. Toxicol. Lett. 78:245-52.

Pope C, Karanth S and Liu J (2005): Pharmacology and toxicology of cholinesterase inhibitors: uses and misuses of a common mechanism of action. Environ. Toxicol. Pharmacol.19(3):433-46.

Ranjbar A, Solhi H, Mashayekhi FJ et al., (2005): Oxidative stress in acute human poisoning with organophosphorus insecticides: a case control study. Environ. Toxicol. Pharmacol. 20: 88 - 91.

Rojas-García AE, Solís-Heredia MJ, Piña-Guzmán B et al., (2005): Genetic polymorphisms and activity of PON1 in a Mexican population. Toxicol. Appl. Pharmacol. 205:282-9.

Singh S, Kumar V, Thakur S et al., (2011): Paraoxonase1 genetic polymorphisms and susceptibility to DNA damage in workers occupationally exposed to organophosphate pesticides. Toxicol. Appl. Pharmacol. 252(2):130-7.

Sirivarasai J, Kaojarern S, Yoovathaworn K et al., (2007):Paraoxonase (PON1) polymorphism and activity as the determinants of sensitivity to organophosphates in human subjectsChem. Biol. Interact.168(3):184-92.

Sözmen EY, Mackness B, Sözmen B et al., (2002): Effect of organophosphate intoxication on human 
serum paraoxonase. Hum. Exp. Toxicol. 21(5):247-52.

Szasz G (1986).Cholinesterase determination in serum with acetyl- and butyrylthiocholine as substrates. Clin. Chim. Acta. 19(2):191-204.

Veiga L, Silva-Nunes J, Melão A et al., (2011): Q192R polymorphism of the paraoxonase- 1 gene as a risk factor for obesity in Portuguese women. Eur. J. Endocrinol. 164(2):213-8.

Yamada Y, Takatori T, Nagao M et al., (2001): Expression of paraoxonase isoform did not confer protection from acute sarin poisoning in the Tokyo subway terrorist attack. Int. J. Leg. Med. 115:82-4.
Yurumez Y, Yavuz Y, Saglam H et al., (2009): Electrocardiographic findings of acute organophosphate poisoning. J. Emerg. Med. 36(1):39-42.

Zayed AA, Ahmed AI, Khattab AM et al., (2015):Paraoxonase 1 and cytochrome P450 polymorphisms in susceptibility to acute organophosphorus poisoning in Egyptians. Neurotoxicology. 51:20-6.

Zhang JW, Lv GC and Zhao Y (2010): The significance of the measurement of serum xanthine oxidase and oxidation markers in patients with acute organophosphorus pesticide poisoning. J. Int. Med. Res. 38(2):458-65.

الملخص العربي

\section{تعدد أشكال جين بار أوكسونيز ا و نشاطه الإنزيمى كعلامة|إنارية فى حالات التسمم بمبيدات مثبطات} الكولينيستريزبين المصرينين الإينين كعلئين

يعتبر إنزيم بار الوكسونيز ا (PON1) واحد من الاستيريز ات ذات النوع (A) المرتبطة بالبروتينات الدهنية عالية الكثافة وهو

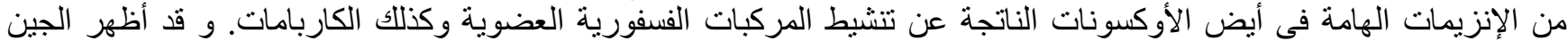

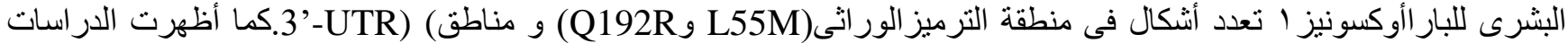

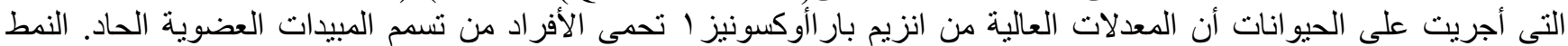

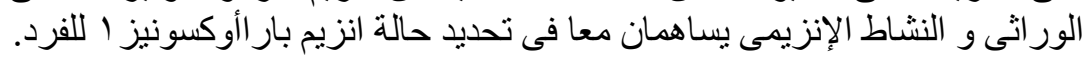

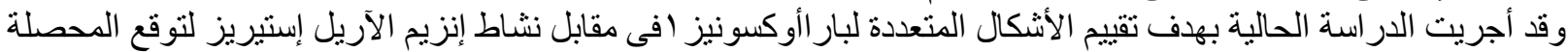

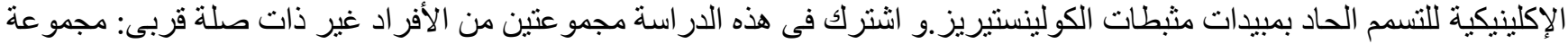

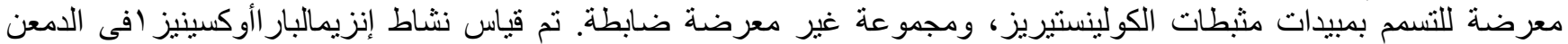

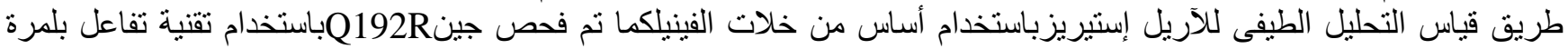

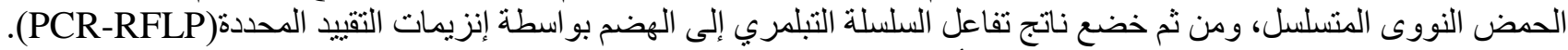

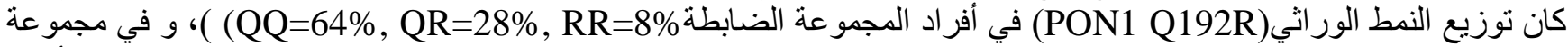

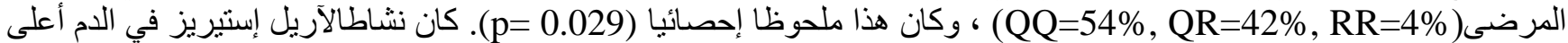
بكثير في المجموعة الضابطة من المجموعة المعرضة. وفيما يتعلق بتأثير النمط الوراثي)(Q192R) و كذللك نشاط إنزيم الآريل

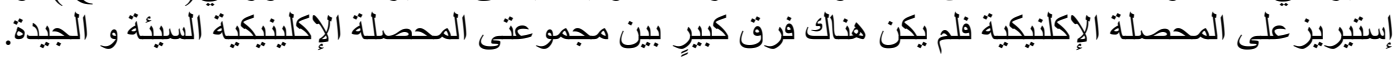

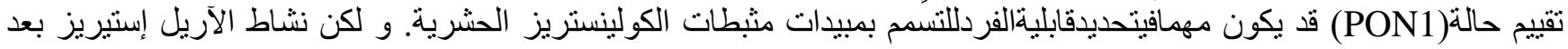

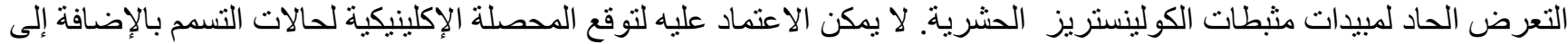

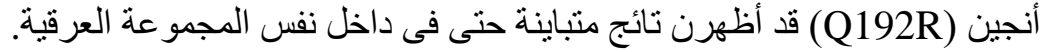

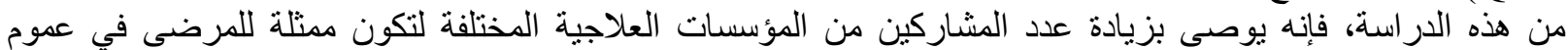

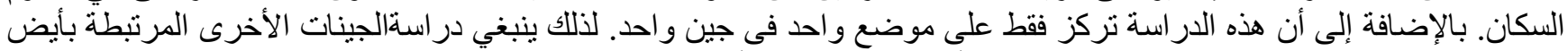

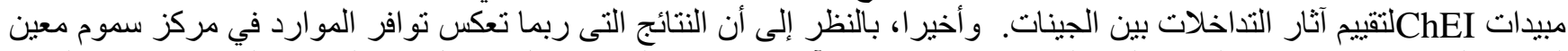

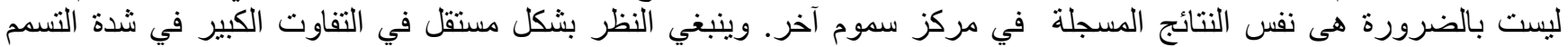
و الاستجابة للعلاج بين المبيدات الفسفورية العضوية و كذللك الكاربامات في مر اكز السموم المختلفة في الدر اسات المستقبلية. 